\title{
E-KÖZIGAZGATÁS ÉS AGRÁR-SZAKIGAZGATÁS MAGYARORSZÁGON
}

\author{
Nagy Elemérné dr. ${ }^{(1)}$ - Hampel György ${ }^{(2)}$ - Fabulya Zoltán ${ }^{(3)}$ \\ ${ }^{(1)}$ föiskolai tanár, ${ }^{(2)}$ föiskolai adjunktus, ${ }^{(3)}$ fỏiskolai adjunktus \\ Szegedi Tudományegyetem Mérnöki Kar
}

\begin{abstract}
The aim of our paper is to give an overview of the electronic public administration and the agrarian administration in Hungary.

The size of the administration affects economic growth: it consumes 35 to 49 percent of the GDP in the European countries. By introducing electronic services, more than 5 percent of the administration costs can be saved. The efforts to digitize are based on the e-Europe programme with the objective to create an information society for everyone.

After creating the legislative background in the past years, administration offices could digitize their registry and could start to offer more and more electronic services to the citizens and organizations. Although the level of digital literacy should be raised among the citizens and the civil servants as well, Hungary can be proud of the quality of the electronic administration services which is above the EU28 average.

The agrarian administration needs a lot of data which is collected and processed by information systems obligatory in the European Union. The collected data is required to effectively operate the agriculture and to access European agricultural subsidies. In the past few years efforts were made to catch up with the European agrarian information systems and today these systems are able to provide the necessary information for the administration and the farmers as well.
\end{abstract}

\section{Bevezetés}

Publikációnk első részében áttekintjük az elektronikus közigazgatás helyzetét, az igénybe vehető szolgáltatások körét, a terület jelenlegi és a jövöbeli kihívásait, eddigi eredményeit és jövőbeli céljait. A második részben szólunk - a részben közigazgatásra épülő - agrárszakigazgatás feladatairól, céljairól, továbbá e szakterület müködéséhez szükséges, kötelezően müködtetendö információs rendszerekről.

A számítógép megalkotásával történelmi jelentöségü innováció került az emberiség birtokába. Az utóbbi két-három évtizedben a számítástechnika elemeinek és rendszereinek teljesítménye jelentős mértékben nőtt, alkalmazhatósága kitágult, elterjedéséhez a gazdasági, müszaki és társadalmi feltételek kedvezỏvé váltak. A számítógép ma már behatolt az élet szinte minden területére, és integrálta, újraformálta a fejlett országok egész termelési és társadalmi tevékenységét. (Mehlhoffer, 2007)

Korábban az adat és információ mozgása, feldolgozása az emberi agy közvetlen lehetöségeinek arányában történt. A számítógép alkalmazása azonban megsokszorozza a lehetőségeket, az informatika segítségével számos logikai folyamat az emberi agyon kivül is elvégezhető. Ezzel lehetővé vált, hogy számos területen a számítógép felgyorsítsa a fejlődést, átformálja az ipari, kereskedelmi és az igazgatási tevékenységet, és ezáltal folyamatosan átalakitotta környezetét. (Mehlhoffer, 2007) 


\section{Közigazgatás}

\subsection{A közigazgatás}

A közigazgatás azon szervezetek összessége, amelyek közhatalmat gyakorolva, az állam vagy az önkormányzat nevében közfeladatokat látnak el és jogszabályokat hajtanak végre. A helyi közügyekben az önkormányzati közigazgatás, az országos jelentöségü ügyekben a központi közigazgatás jár el. Az egyes közigazgatási szervek, szervezetek hatalmát területi szempontból az illetékességiuk, az általuk lefolytatható eljárások típusa szempontjából a hatáskörük határozza meg. A közigazgatási eljárást hivatalból vagy a közigazgatás ügyfeleinek kérelmére a köztisztviselők folytatják le. (Wikipédia, 2007)

A közigazgatás mérete és súlya hatást gyakorol gazdaság növekedésére - Európában a GDPnek átlagosan 35-49\%-át emészti fel; számos országban a közigazgatás a legnagyobb piaci megrendelök közé tartozik. Egy elektronizált közigazgatás a költségek több mint 5 százalékát is megtakarithatja, így az e-szolgáltatások elterjedtsége valóban fontos kérdésként vetődik fel. (Molnár et. al., 2006)

A magyar közigazgatással szemben a legnagyobb kihívás az Európai Unióhoz való csatlakozásból ered.

A közigazgatás teljesítőképességének emelése egyrészt gazdasági, másrészt etikai okok miatt is szükséges. A közigazgatás teljesítőképességének növelése alapvető fontosságú, azért, hogy az mindenki hasznára müködjön, továbbá a magyar közigazgatásnak eredményesen kell megvalósítania az Európai Közigazgatási Térbe való illeszkedését is.

Bár a közigazgatás kialakítása, szervezése és müködtetése nemzeti hatáskör, az Európai Unió több lépést is tett az egységesebb közigazgatási tér kialakítására. A tagállami közigazgatások fejlödését azonban nemcsak az európai, hanem a tágabb értelemben vett nemzetközi folyamatok is befolyásolják: a költségvetés helyzetének javítása, az állampolgárok megnövekedett elvárásainak kielégítése, az eredményesség javítása és egyéb kihívások figyelembe vétele nemcsak az Európai Unió tagállamaiban, hanem a világ más országaiban is fontos szempont. Tehát elmondható, hogy a közigazgatás európaizálódását kiváltó folyamatok mellett a társadalom modernizálódásához kapcsolódó követelmények is meghatározzák a nemzeti közigazgatás, illetve közszolgálat átalakítását. (Dudás, 2008)

\subsection{A közigazgatás digitalizálása}

Az Európai Bizottság 1999-ben hozta nyilvánosságra programtervezetét, amely az e-Europe nevet viselte. Ennek a programnak fontos részét képezi az on-line kormányzás és az elektronikus közigazgatás. Az e-Europe központi üzenete maga a cím: Információs társadalmat mindenkinek! A második üzenet, hogy a digitális korszak technikailag lehetséges alkalmazásaival törekedjünk az életminőség javítására, kezdve az elektronikus kereskedelemtől az on-line egészségügyig. A harmadik átfogó üzenet az, hogy az elektronikus Európa megerösödése érdekében a tudásgazdaság, az információs gazdaság fontosabb alkalmazásait (e-kereskedelem, intelligens kártya, stb.) gyorsan és minél szélesebb körben kell elterjeszteni.

A program a demokráciamodell megújítását is követeli az on-line kormányzásra való áttéréssel. (Király, 2002)

Az e-közigazgatás célja elektronikus csatorna létrehozása az önkormányzatok, a lakosság, valamint a különböző szervezetek között, illetve ennek a kapcsolatnak minél szélesebb körü 
alkalmazása és hasznosítása; így korszerü, szolgáltató és ügyfél centrikus ügyintézés valósulhat meg.

Az e-közigazgatás legföbb feladatai: információk közzététele a világhálón, az állampolgárok hatékony tájékoztatása, az ügyfélszolgálatok tehermentesítése, valamint interaktív szolgáltatások és e-ügyintézés az interneten keresztül. Ehhez a közigazgatás digitalizálása szükséges, amelynek több, egymásra épülö lépéseit a következö: (Varga, 2007)

- Első lépés: A technológiai modernizálás; a megfelelö informatikai infrastruktúra kiépítése.

- Második lépés: A belsö e-ügyintézés elterjedése; a közigazgatási szerveken belüli teljes ügyintézés számítógépre vitele, az elektronikus iroda (részleges) megvalósítása.

- Harmadik lépés: Az állampolgári ügyintézés interneten keresztüli megvalósítása; közigazgatási szolgáltatások számitógép-hálózaton történö igénybevétele.

- Negyedik lépés: Az állampolgári e-részvétel a döntések elökészítésében és végrehajtásában; szoros kétirányú kapcsolat kialakítása az állampolgár és a közigazgatás között.

- Ötödik lépés: e-Választás a virtuális térben, úton az e-demokráciába.

Az Európai Unió országainak közigazgatása - így Magyarországé is - jelenleg a harmadik lépés megvalósításánál tart.

Az Európai Bizottság 2005 évben közreadott felmérése szerint az új tagok az e-közigazgatás terén átlagosan két évvel voltak lemaradva a régiektől. Magyarország felkészültsége ezen a téren hasonló a kömyező országokéhoz, a középmezőnybe tartozik. (Molnár et. al., 2006)

\subsection{Jogszabályi háttér}

Korábban a számítógépek - elsösorban jogszabályi korlátok miatt - az egyedi ügyintézésben csak annyiban kaptak szerepet, amennyiben a megfelelö papír dokumentum elöállítását szolgálták. Ez a gyakorlatban szövegszerkesztési, majd ügyviteli támogatást jelentett. A térinformatikai rendszerek megjelenésével érdemi szakhatósági támogatást kezdett adni az informatika.

Az ezredforduló környékén már emberek százezrei tértek át az interneten keresztüli elektronikus ügyintézésre (levelezés, banki tranzakciók, on-line vásárlás stb.). Emellett a közigazgatási szervek adatbázisait sorra digitalizálták (például a nyugdij- és egészségbiztosítás, valamint a földhivatalok adatait), és kezdtek kezdetleges elektronikus szolgáltatásokat nyújtani (adó-, munkaügyi adatbázis stb.). Az államigazgatási eljárás azonban ezalatt csaknem érintetlen maradt. (Mehlhoffer, 2007)

A közigazgatás elektronikussá tételéhez először meg kellett oldani annak hitelessé tételét. Ezt szolgálta a 2001. évi XXXV. törvény az elektronikus aláirásról. Majd a következő - radikális - lépés a 2004. évi CXL. törvény a közigazgatási hatósági eljárás és szolgáltatás általános szabályairól szóló törvény volt, ami újabb elmozdulást jelentett az információs társadalom felé.

Az új jogszabályból fakadó első következmények nem az ügyfelekkel történő elektronikus ügyintézésből, hanem a belsỏ mủködés szabályainak változásából adódnak: a módosított levéltári törvénynek, a közigazgatási eljárási törvénynek, valamint a kormány- és miniszteri rendeleteknek a továbbiakban csak erre a célra tervezett iratkezelési szoftverek birtokában lehet megfelelni.

A jogszabályok az informatikai rendszerek közigazgatási célú felhasználásának több területét szabályozzák, így: (Kovács, 2007)

- a hatóság és az ügyfél közötti elektronikus kommunikáció folyamatát,

- az ügyfél azonosítását, 
- a felhasznált szoftver- és hardvereszközökkel kapcsolatos követelményeket (dokumentumkezelés, interoperabilitás, formátumok),

- minőségbiztosítási és információbiztonsági menedzsment követelményeket határoznak meg a rendszerek tervezésével, fejlesztésével és üzemeltetésével kapcsolatban.

2007. január 1-jétől kizárólag a 16/2006 (IV. 6.) BM rendelet alapján kijelölt minősitő szervezet által tanúsított iratkezelési szoftvert lehet megvásárolni. 2008. január 1-tỏl pedig a közfeladatot ellátó szervezetek kizárólag tanúsítvánnyal rendelkező iratkezelési szoftvereket használhatnak.

\subsection{E-szolgáltatások}

Az e-közigazgatás előnyei között említhetjük, hogy így lehetővé válik az emberi erőforrások megtakaritása, ami hatékonyabb ügyintézést eredményez. Az elektronikus úton történő ügyintézés mind az állampolgárok, mint a hivatalok szảmára idỏmegtakarítást jelent. Az adminisztrációban dolgozóknak kevesebb időt kell fordítaniuk ürlapokkal kapcsolatos munkákra, így az adminisztráció egyszerüsödésével, a többszöri munkavégzés kiküszöbölésével csökkennek az ügyintézés költségei és hibalehetőségei. Kialakul az edemokrácia; a portálokon keresztül nyilvánossá válik az önkormányzatok és a különböző szervezetek munkája lakosság számára is.

Az e-szolgáltatások teljesítménye szoros korrelációt mutat a GDP-vel, valamint a gazdasági versenyképességgel: Azokban az országokban, ahol magas az egy före jutó bruttó hazai termék, ott általános e-kormányzati stratégiával rendelkeznek, kifinomult online szolgáltatásokat kínálnak és a közszolgáltatások modernizációját a minisztériumi hierarchiába illeszkedő, önálló intézmény végzi. A szegényebb országokban az e-közigazgatás területe nem nyer önálló prioritást, csupán az információs társadalom megvalósitásának egyik részterületeként kerül meghatározásra és az online szolgáltatások szintje is jóval alacsonyabb. Az e-közigazgatási teljesítmény szoros korrelációt mutat az internet elterjedtségével is. Az online közszolgáltatások sokszínüsége szorosan összefügg azzal is, hogy az informatikai irástudás szintje mennyire magas. (Molnár et. al., 2006)

A számítógépet a közigazgatásban elsösorban olyan feladatokban lehet hatékonyan alkalmazni, amelyek nagyobb adatbázis(ok) kezelését teszik sziikségessé. Néhány ezek közül a nyilvántartások közül: (Mehlhoffer, 2007)

- személyi nyilvántartások;

- lakásigénylések nyilvántartása;

- légszennyezők és szennyezések adatainak nyilvántartása;

- városi útnyilvántartás;

- első ízben munkába lépők nyilvántartása;

- munkaerőigények és munkaerö-közvetítés nyilvántartása;

- szociális gondoskodást igénylők nyilvántartása;

- beruházások nyilvántartása;

- pénzügyi ágazat pénzforgalmának nyilvántartása;

- ingatlanok forgaimi értékének nyilvántartása;

- mezőgazdasági haszonbérlők nyilvántartása;

- sportolók adatainak ás az egyesületek költségvetésének nyilvántartása;

- kisajátítások nyilvántartása;

- szabálysértések nyilvántartása;

- önkormányzati feladatok nyilvántartása; 
- önkormányzati utak forgalmi jelzéseinek nyilvántartása;

- kisvállalkozások nyilvántartása;

- helyiség-nyilvántartás;

- településfejlesztési hozzájárulás nyilvántartása;

- a lakosság komplex egészségügyi szürésének nyilvántartása;

- iktatási nyilvántartás.

Ezek a digitalizált nyilvántartások elsősorban a közigazgatás belsỏ mủködési folyamatainak segitését szolgálják. Vannak olyan elektronikus szolgáltatások, amelyek kifejezetten az állampolgár (vagy vállalkozás) és a közigazgatás között kapcsolat hatékonyságának növelésére, könnyítésére szolgálnak. Néhány ezek közül:

- általános információnyújtás, tájékoztatás interneten keresztül (például jogszabályok, közigazgatási eljárások menete, intézkedések, tervek stb.),

- időpontfoglalás személyes ügyintézéshez,

- adóbevallás elektronikus intézése,

- nyugdíjjal kapcsolatos ügyintézés,

- cégbírósági elektronikus ügyintézés,

- egyéb elektronikus adatszolgáltatás a hivatal felé (például adatszolgáltatás letiltása, gázár-támogatás igénylése stb.).

Ahogy a hagyományos ügyintézéshez szükség van az írni-olvasni tudás képességére, az elektronikus ügyintézéshez a "digitális írástudás" képessége szükséges. A számítógép bonyolult eszköz és a társadalom nagyobb része még nem rendelkezik olyan szinten ezzel a tudással, hogy jogainak csorbulása nélkül mindenütt elö lehessen írni kötelező használatát. Ugyanakkor a kor követelményeinek megfelelően az ügyfelet megilleti az elektronikus ügyintézés igénybe vételének joga.

Figyelemre méltó az a jelenség, hogy a magyarországi internetezök csoportján belül elsősorban a középkorúak és az idősebb korosztály érdeklődik az online ügyintézési lehetőségek iránt. Ugyanakkor ennek a felhasználói rétegnek az aránya még olyan kicsi, hogy kevésbé érvényesül az az állampolgári, felhasználó nyomás, ami kényszeritő erővel hatna a közigazgatás elektronikussá tétele irányába.

Az e-közigazgatás igénybevételéhez nem csak az ügyfél oldalról szükséges a megfelelö informatikai ismeret, hanem a közigazgatási hivatalok munkatársaitól is elvárható a legalább felhasználói, vagy akár annál magasabb szintü informatikai ismeret.

A közigazgatási hivatalok dolgozói az alapvető számítástechnikai ismeretek, mint az operációs rendszer és az irodai programcsomagok kezelésének képessége, képesek kell legyenek különbözö, nyilvántartásokhoz kapcsolódó információs rendszerek használatára is.

\subsection{Az elektronikus közigazgatás kihívásai}

Az elektronikus közigazgatás bevezetése és müködtetés több megoldandó problémát vetít elöre. A következökben felsorolt tényezök közül több részben már megoldott, más részük még megoldásra vár:

A közigazgatási szervezetek belsö ügyviteli folyamatainak interaktív elektronikus rendszerre történö átalakítása után azt fel kell bontani egyrészt egy klasszikus interaktiv integrált közigazgatási rendszerre, valamint a lakossági hozzáférést is lehetővé tevő rendszerre.

Módosítani kell a közigazgatási szervezeteken belüli kapcsolatrendszert, amihez szakszerü közigazgatás-szervezési átalakítás szükséges. Meg kell változtạtni a korábbról örökölt eljárási-döntési mechanizmusokat. Az új technológia csak akkor hidalja át az információcsere útjában álló időbeli és fôldrajzi távolságokat, ha sikerull áttörni a hierarchikus és bürokratikus 
korlátokat és megkönnyítik a hivatalokon belüli vertikális és horizontális információáramlást. Az alapnyilvántartások (cég-, telek-, ingatlan-, gépjármũ tulajdonos- és forgalmi engedély-, személy- és lakóhely nyilvántartások, közműtérképek stb.) megbízható adatokkal való feltöltését meg kell oldani. Az adatok megbízhatósága növelhető és az „egy adatot csak egyszer megadni" elv érvényesithető az adatbázisok szabályozott és korlátozott összekapcsolásával.

Fejlett távközlési infrastruktúrát kell kiépíteni, amely megfelel az e-közigazgatással kapcsolatos társadalmi és állampolgári igényeknek. Minden állampolgárnak és vállalkozásnak elérhetỏ áron hozzáférhetỏvé kell tenni az információs hálózatokat és szolgáltatásokat.

A regionális, megyei vagy esetleg kistérségi távoktatási programok kiemelt feladata kell legyen a köztisztviselők felkészitése az e-közigazgatás feladatainak ellátására, beleértve a számítástechnikai és internet-alapismeretek elsajátítását is. (Király, 2002)

Noha a magyar kormányzat rövid idő alatt igen sok eredményt ért el, továbbra is megmaradt néhány fontos belsö kihívás, amelynek meg kell felelni.

- Ezek között van a szabályozási és a költségvetési keretrendszereknek a rugalmasság növelését, az együttmüködés elösegítését és a források átcsoportosíthatóságát célzó frissítése.

- A magyar társadalom viszonyai között rendkívül komoly eröfeszítéseket kell tenni a digitális szakadék csökkentésére és a szélessávủ hozzáférés javítására annak érdekében, hogy a e-szolgáltatások szélesebb körben terjedjenek el, továbbá, hogy az elektronikus kormányzat fejlesztése folyamatosan, haladjon elöre.

- A kommunikációs és oktatási programoknak folyamatosan szem elỗt kell tartaniuk az informatikai készségek növelését, és annak elősegitését, hogy a mind a kőztisztviselök mind pedig az állampolgárok is megértsék a digitalizálásból fakadó előnyöket. (Mező, 2007)

\subsection{Az elektronikus közigazgatás eddigi eredményei és további céljai}

Magyarország sikeresen teljesítette az Európai Unió által értékelt húsz elektronikus szolgáltatás biztosítását, söt, további erőfeszítéseket is tett, hogy az elektronikus szolgáltatások körét tovább bővítse. Mára már Magyarországnak az elektronikus közigazgatási szolgáltatások kifinomultságára vonatkozó teljesítménymérések alapján sikerült az EU-28 tagállamok átlagértékei fôlé emelkednie.

Mivel a legtöbb szolgáltatás egészen új, a szolgáltatások igénybevételi szintje - azok magas kidolgozottsági szintje ellenére - továbbra is alacsony. Igaz, elmondható, hogy a közelmúltban jelentősen növekedett a felhasználók érdeklödése ezen szolgáltatások iránt. (Mezö, 2007)

A központi elektronikus kormányzat sikeresen csatlakozott az Európai Unió infrastrukturális rendszereihez és megteremtödtek az elektronikus közigazgatás integráciojának alapját biztosító Központi Elektronikus Szolgáltató Rendszer elemei is. A következö évek feladata az elektronikus ügyintézés kiterjesztése a közigazgatás egészére.

A legkeresettebb szolgáltatások teljes körü elektronizálása, az e-fizetés megteremtése, valamint a biztonságos azonosító rendszer bevezetése a legföbb cél a kormányzati elfogadásra váró középtávú elektronikus közigazgatás stratégiában. A tervek szerint két éven belül otthonról intézhetünk szinte már minden hivatalos ügyet, feltéve, hogy sikerül a fejlesztéseket a tervek szerint megvalósítani.

A jövőbeni célkitủzések között az elektronizáltság és a szolgáltatások hatékonyságának a növelését, a pán-európai müködés megalapozását jelölte meg az elfogadásra váró Eközigazgatás 2010 középtávú kormányzati stratégia, amely kiemelt feladatnak tekinti, hogy a 
jövőben minél szélesebb körben vegyék igénybe az állampolgárok és vállalkozások az új technikai lehetőségeket. (Farkas, 2008)

\subsection{Néhány közigazgatási honlap és szolgáltatás}

Szeretnénk felhívni a figyelmet néhány olyan honlapra, amelyeken keresztül az eközigazgatás körébe tartozó, különböző minőségű szolgáltatások vehetők igénybe:

- Miniszterelnöki Hivatal (www.meh.hu) - célja elsősorban az egyoldalú, a hivataltól az állampolgároknak és szervezeteknek felé történő tájékoztatás, információközlés.

- Szeged Megyei Jogú Város Önkormányzata (www.szegedvaros.hu) - célja szintén elsősorban az egyoldalú, a hivataltól az állampolgároknak és szervezeteknek felé történö tájékoztatás, információközlés, azonban az előbbitől eltérően helyi, önkormányzati szinten.

- Szeged Megyei Jogú Város Polgármesteri Hivatala önkormányzati portál (https://eservices.szeged.eu/eku/ugytipusok.php) - alapszintü elektronikus ügyintézés biztosítása az ügytípusnak megfelelö dokumentumok letöltésének biztositásával.

- Magyarország (ügyfélkapu) (www.magyarorszag.hu) - a legátfogóbb elektronikus közigazgatási szolgáltatás biztosítása, tájékoztatás jogszabályokról, közigazgatási eljárásokról, időpontfoglalás, egyes ügyek részleges, vagy teljes elektronikus módon történő intézésének biztosításával.

\section{Agrár-szakigazgatás}

\subsection{A magyar agrárgazdaság céljai}

Az agrárgazdaság fejlesztéséröl szóló 1997. évi CXIV. törvényt az Országgyülés annak érdekében alkotta, hogy

- a magyar agrárgazdaság hosszútávra szóló, környezeti szempontból fenntartható és széles körü közmegegyezésen alapuló fejlődését elősegítse;

- megteremtse az agrárfejlesztés kiszámítható és konjunkturális okokból meg nem kérdőjelezhető tartós kereteit;

- kijelölje a gazdasági és társadalmi célokat, meghatározza az alapvető fejlesztési elveket és a megvalósításhoz szükséges eszközöket;

- segítse a mezögazdasági foglalkoztatást, és hozzájáruljon a mezőgazdasági termelök életszínvonala javításához, jövedelemszerzési lehetőségeinek a társadalmi átlaghoz való közelítéséhez, erösítse a vidék lakosságmegtartó képességét;

- elösegítse az Európai Unió keretei között a versenyképes gazdálkodást, a szerkezetváltást, a széles körü agrár-környezetgazdálkodást, valamint az ehhez szükséges adatbázis és intézményrendszer müködtetését.

A magyar agrárgazdaságban a következő célokat kell érvényesíteni:

- a termelés versenyképességének javítása, a mezőgazdasági termelés és a piaci szabályok feltételeinek olyan alakítása, amelynek eredményeként megfelelö mennyiségben és minőségben legyen kielégíthető a lakosság élelmiszerszükséglete, a környezetkímélö gazdálkodás és az élelmiszerbiztonság szakmai szabályai szerint;

- a nemzetgazdaság más ágazataihoz viszonyított esélyegyenlőség megteremtése, hogy a mezőgazdaságból élők arányos tỏke- és munkajövedelmet szerezhessenek meg;

- az agroökológiai adottságokra alapozott termelés folytatása, amely képes kihasználni a természeti és gazdasági adottságok nyújtotta elönyöket;

- vidékfejlesztéssel és a foglalkoztatás növelésével hozzájárulás a vidéken élök életminőségének javitásához, ezáltal a vidék lakosságmegtartó képességének nőveléséhez; 
- a szabályozó, ösztönző és támogatási rendszer segítse a termelés és a környezeti érdekek közötti összhang megteremtését, a kömyezetkímélő gazdálkodás és a vidékfejlesztési célok megvalósulását;

- a környezetvédelem és természetvédelem integrálásával valósuljon meg a mezőgazdaság fenntartható fejlỏdése;

- az agrárgazdaság emberi erõforrásainak fejlesztése, az agrár-innováció elősegítése;

- alternatív jövedelemforrások létrehozásának ösztönzése, elősegítése.

\subsection{Az agrár-szakigazgatás}

A szakigazgatás szervei a közigazgatás részeként, egy-egy szakterület irányítójaként, információgyüjtöjeként mükơdnek a közigazgatáson belül, annak (részleges) felügyelete alatt: „A kőzigazgatási hivatal a Kormány kijelölt területi államigazgatási szerve.... A közigazgatási hivatal közvetlenül a közigazgatási hivatal vezetöjének ... vezetése alatt álló szervezeti egységekből, továbbá kormányrendeletben meghatározott ágazati szakigazgatási szervből ..., valamint - a Közép-magyarországi Regionális Közigazgatási Hivatal kivételével - kirendeltségekböl áll..." (177/2008. (VII. 1.) kormányrendelet)

Az országban a Földművelésügyi és Vidékfejlesztési Minisztérium irányításával 2007-töl müködik a Mezőgazdasági Szakigazgatási Hivatal. Feladatai közé tartozik az agrárpiaci rendtartás müködésének szervezésével és ellenörzésével kapcsolatban a hatósági és mezögazdasági szakigazgatási feladatok ellátása a következő terülteken:

- növénytermesztés, állattenyésztés, genetikai anyagok megõrzése,

- növényfajták állami elismerése, növényi szaporítóanyagok minősítése,

- borgazdálkodás,

- vadgazdálkodás és halászat,

- erdőgazdálkodás és az erdővagyon védelem, elsődleges faipari termelés, és ezekhez kapcsolódó szolgáltatások;

- mezőgazdasági termékforgalom,

-. agrár-környezetvédelem,

- növényvédelem,

- talajvédelem,

- állategészségügy,

- takarmánybiztonság, takarmányhigiénia, takarmány-minőség,

- élelmiszerhigiénia, élelmiszer-biztonság, élelmiszer-minőség,

- állatgyógyászati termékek,

- vágóállatok vágás utáni minősítése,

- állatvédelem,

- mezőgazdasági célú vízgazdálkodás.

Ezen kívül a Hivatal ellátja földügyi igazgatási és hatósági feladatokat, az alaptevékenységéhez tartozó kutatási, fejlesztési, laboratóriumi, vizsgálati, tanácsadási, szakértői, tervezési és egyéb feladatokat is. (FVM MgSzH, 2007)

\subsection{Az agrár-információs rendszerek működtetésének feltételei és céljai}

A hatékonyan müködő igazgatáshoz az adatokkal és információkkal kellően megalapozott döntések meghozatalához, számítógéppel támogatott információs rendszerek, valamint megfelelően frissített, pontos - és minél szélesebb körü adatokat tartalmazó - adatbázisok szilkségesek. (Horváth, 2002)

Sokszor jelentett problémát, hogy az 1990-es évek elején összeomlott az ország agrár- 
információs rendszere, mivel ennek következtében nem voltak megbízható és hozzáférhető adatok sem a termelők, sem az agrár-szakigazgatás számára. Az elmúlt közel két évtizedben, egyrészt nőtt az információs igények és az információszolgáltatás közötti rés, másrészt gondot okozott a már megszerzett információkhoz való hozzáférés is; részben az adatok monopolizálása miatt, részben pedig azért, mert a termelök nem tudták, hogy hol érhetök el a szükséges információk. (Kapronczai, 2007)

Mára - az Európai Unióhoz való csatlakozással - az Unió által megkövetelt agrárinformációs rendszerek kötelezö müködtetésével jelentősen változott a helyzet. Ezzel együtt van néhány olyan szempont, ami nélkülözhetetlen ahhoz, hogy a már kiépült agrárinformációs rendszerek megfelelö információkat biztosítsanak mind a termelök, mind az agrár-szakigazgatás számára:

- Esélyegyenlöség: Minden termelö számára biztositani kell a döntésekhez szükséges információt, egyik termelő sem kerülhet elönybe, vagy hátrányba.

- Kölcsönös információszolgáltatás: Az agrárinformációs rendszerek megfelelő müködéséhez, az információszolgáltatáshoz szükséges, hogy a termelök megfelelö adatokkal lássák el azt.

- Állami kényszerités: Egyes adatok szolgáltatását jogszabály írhatja elő, ez általában a kötelező statisztikai adatszolgáltatást jelenti.

- Önkéntesség: Az agrárinformációs rendszerek általában reprezentatív, (nem teljes körü, minden adatot tartalmazó) rendszerek, amelyben jelentős szerepe van - különböző ösztönző eszközökkel elösegítve - a termelök önkéntes adatszolgáltatásának is.

- Bizalom és anonimitás: Az információszolgáltatás ösztönzése érdekében elengedhetetlen az adatszolgáltató termelő részéről meglévő bizalom. Ehhez a termelőnek biztosnak kell lennie abban, hogy adataival nem élnek vissza, továbbá az adatok információs rendszeren belüli kezelése biztosítja az anonimitást.

- Érdek: Szükséges a termelök érdekelté tétele, akár pénz, akár megfelelö információszolgáltatás, szaktanácsadás formájában. (Kapronczai, 2007)

Az agrárinformációs rendszereknek és a hozzájuk kapcsolódó adatbázisok kiépítésének négy fő célja: a vállalkozások tevékenységének segítése, az agrárkormányzatnak elvárásainak való megfelelés, az unió igényeinek kielégítése, valamint a közvélemény tájékoztatása, az oktatás és kutatás támogatása.

\subsection{Információs rendszerek az agrár-szakigazgatásban}

Az Európai Unióhoz való csatlakozás tehát jelentős változást hozott a magyar agrárgazdaság helyzetében. Ahhoz, hogy az agrár-szakigazgatás új és komplex feladatait hatékonyan legyen képes ellátni, továbbá az agrárszektor hozzájuthasson az uniós támogatásokhoz, megfelelően müködő információs rendszerre van szükség.

Bár Magyarország a csatlakozás előtt jelentős lemaradásban volt az agrárinformációs rendszerek kiépítése és használata terén, ezt mára már sikerült ledolgozni. A magyar agrárinformációs rendszer alapját öt nagy információs rendszer jelenti, ezek a statisztika, a Tesztüzemi Rendszer, a Piaci Információs Rendszer, az Integrált Igazgatási és Ellenőrző Rendszer, továbbá a Mezőgazdasági Számlarendszer: (Kapronczai, 2007)

- Az agrárstatisztika az EUROSTAT koordinálásával szerteágazó területeken gyüjt és nyújt statisztikai jellegü információkat az Unión belüli folyamatokról, a föbb tendenciákról.

- A Tesztüzemi Rendszer feladata a gazdaságok pénzügyi folyamatainak, jövedelemhelyzetének nyomon követése.

- A Piaci Információs Rendszer egyrészt a termelők, másrészt a brüsszeli apparátus információigényeinek kielégitését szolgálja. 
- Az Integrált Igazgatási és Ellenőrző Rendszer egy technikai jellegủ információs rendszer, ami elsősorban az Unió adminisztrációjának mủködését segíti: a támogatások elnyerését szolgáló információs rendszer, ami az adófizetők pénzéből történő kifizetések elszámolását és ezek ellenőrzését végzi.

- A Mezõgazdasági Számlarendszer feladata az Unió által megadott termékkörre vonatkozó termelési, felhasználási, technológiai adatok konzisztens összefogásával a termelési érték, a hozzáadott érték és a jövedelempoziciók dokumentálása, elörejelzése, továbbá agrárpolitikai intézkedések várható hatásainak becslése:

\subsection{Agrárgazdasággal kapcsolatos honlapok}

Végezetul a magyar agrárágazathoz kapcsolódó rengeteg honlap közül csupán néhányra szeretnénk felhívni a figyelmet:

- Földművelésügyi és Vidékfejlesztési Minisztérium: www.fvm.gov.hu - célja a szakterülethez kapcsolódó tájékoztatás, információközlés.

- Mezőgazdasági Szakigazgatási Hivatal: www.ommi.hu - célja elsősorban a termelők tajékoztatása, információközlés.

- Központi Statisztikai Hivatal mezögazdasággal kapcsolatos adatbázisa: portal.ksh.hu/portal/page?_pageid=37,597167\&_dad=portal\&_schema=PORTAL - célja a mezögazdasággal kapcsolatos statisztikai adatközlés.

- Agrárgazdasági Kutató Intézet: www.akii.hu - célja az agrárgazdasághoz, agrárpolitikához kapcsolódó elemzések, adatok, valamint a Tesztüzemi Információs rendszer adatainak közzététele.

\section{Irodalomjegyzék}

Dudás Ferenc (2008): A magyar közigazgatás teljesítőképességének növelése a kihívások tükrében. Vezetői tudás.

http://www.vezetoitudas.hu/pages/articles.aspx?id=A21CFFCF-A9DC-465C-9481 1BF8BE05D02C (2008.09.10.)

Földmüvelésügyi és Vidékfejlesztési Minisztérium Mezőgazdasági Szakigazgatási Hivatal, http://www.fvm.hu/main.php?folderID=2071, 2007

Farkas Katalin (2008): Néhány év múlva kiürülhetnek a hivatalok. Origo Üzleti negyed. http://www.origo.hu/uzletinegyed/magyargazdasag/20071130-ekozigazgatas.html (2008.09.10.)

Horváth Imre (2002): Közigazgatási szervezés- és vezetéstan. Dialóg Campus Kiadó, Budapest-Pécs.

Kapronczai István (2007): Információs rendszerek a közös agrárpolitika szolgálatában. Szaktudás Kiadó Ház. Budapest.

Király Ferenc (2002): E-közigazgatás Európában és Magyarországon. eVilág. http://www.pointernet.pds.hu/ujsagok/evilag/2002/00/evilag-15.html (2008.09.10.)

Kovács V. Gábor (2007): E-közigazgatási informatikai rendszerek jogi szabályozása. http://www.kovacsvg.hu/C_E-kozigazgatasiRendszerekSzabalyozasa.html (2008.09.10.)

Mehlhoffer Viktor (szerk.) (2008): Az e-kőzigazgatás, mint a digitális írásbeliség része. Govsys. Integrált önkormányzati rendszer. http://www.govsys.hu/index.jsp (2008.09.10.)

Mezö Margit (szerk.) (2007): Az e-kormányzat helyzete Magyarországon. eVilág. http://www.pointernet.pds.hu/ujsagok/evilag/2006ev/12/20070215143419412000000378. html (2008.09.10.) 
Molnár Szilárd et al. (2006): E-közigazgatás - Éves jelentés 2005. BME-UNESCO Információs Társadalom és Trendkutató Központ - INFONIA Alapítvány. Budapest. 2006.

Varga Csaba (2007): Az információs társadalom e-kormányzása, e-önkormányzása, eközigazgatása. Külker Online. http://www.kulker-online.ew/component/option, com_docman/task,doc_download/gid,43/ (2008.09.10.)

in Wikipédia http:/hu.wikipedia.org/wiki/K\%C3\%B6zigazgat\%C3\%A1s (2008.09.10.) 